International Journal of Pharmaceutics \& Pharmacology

EDWASER

Available Online: https://ijpp.edwiserinternational.com

\title{
Coronavirus (COVID-19): History, Current Knowledge and Pipeline Medications
}

\author{
Mohammed Asadullah Jahangir ${ }^{* 1}$, Abdul Muheem ${ }^{2}$ and Midhat Fatima Rizvi ${ }^{3}$ \\ ${ }^{1}$ Department of Pharmaceutics, Nibha Institute of Pharmaceutical Sciences, Rajgir, Nalanda-803116, Bihar, India \\ ${ }^{2}$ Department of Pharmaceutics, School of Pharmaceutical Education \& Research, Jamia Hamdard, New Delhi-110062, India \\ ${ }^{3}$ Tripura Medical College, Hapania, Agartala-799014, Tripura, India
}

Article info

Received 20 March 2020

Revised 29 March 2020

Published 31 March 2020

*Corresponding author: Dr. MA Jahangir, Nibha Institute of Pharmaceutical Sciences, Rajgir, Nalanda-803116, Bihar, India; Email: nipsrajgir@gmail.com

\begin{abstract}
In spite of being characterised in the 1960s, human coronavirus still needs extensive studying for its better understanding. Since, the start of the new millennium corona viruses had caused pandemic. SARS-CoV and MERSCoV were the first coronavirus outbreak which has resulted in socioeconomic and psychological losses in the past. The novel corona virus outbreak (COVID-19) needs lesson from our past experience in tackling the devastating situation. The population needs awareness about this novel virus during the current pandemic situation. In this article the author reviews the history of coronaviruses, its lifecycle and genomic structure, current pandemic situation, diagnosis of COVID-19, preventive measures, current medication and pipeline drugs and diagnostic kits.
\end{abstract}

Keywords: COVID-19; Coronaviruses; Severe Acute Respiratory Syndrome (SARS) Coronavirus; Middle East Respiratory Syndrome (MERS) Coronavirus; Hydroxychloroquine sulfate; Chloroquine phosphate; Favilavir; Remdesivir

\section{History}

Tyrell and Bynoe isolated first human coronavirus in the year 1965 from the respiratory tract of a patient with complain of common cold [1]. The virus was named B814. However, the researchers failed to grow the agent in culture media. In a similar study by Hamre and Procknow, the researchers reported similar kind of virus which they named 229E isolated from the samples obtained from medical students with cold [2]. In another study by McIntosh et al. ether sensitive agents of multiple strains were isolated from human respiratory tract [3]. Since they were grown in organ culture, hence were named "OC" [3]. At about the same period of time Almeida and Tyrrel [4] studied organ cultures infected with B814 exploiting electron microscopy and reported particulates of size $80-150 \mathrm{~nm}$ resembling infectious bronchitis virus of chickens. Astonishingly both $229 \mathrm{E}$ agent identified by Hamre and Procknow and OC virus reported by McIntosh et al. were found to have similar morphology. In the later part of 1960, a group of virologists under the leadership of Tyrell were studying different strains of human and animal viruses which included mouse hepatitis virus, infectious bronchitis virus, transmissible gastroenteritis virus of swine etc. all of them were morphologically same as demonstrated by electron microscopic study. Thus, a new genus of viruses was found which was named CORONA, where the term corona denoted the crown like appearance of the surface in the morphological structure of viruses [57]. Further on-going research with advanced serological techniques resulted in bringing new information's about the epidemiology of the coronaviruses. These viruses occur more in the rainy, winter and spring seasons compared to the summer season [8]. Among the different strains of coronaviruses $229 \mathrm{E}$ and OC43 were the most extensively studied. However, as per Bradburne and McIntosh et al. B814 and other 3 of the 6 strains of previously studied coronaviruses were related to $229 \mathrm{E}$ and OC43 on very few characteristics $[9,10]$. Upon volunteer inoculation and epidemiological study coronaviruses were found to be associated with a 
variety of respiratory illness $[2,8,11,12]$. The predominant illness was found to be pneumonia in children and young adults $[13,14]$. They were also associated with chronic bronchitis and asthma in adults and elders $[15,16]$. Apart from human coronaviruses, the number and epidemiological importance of animal coronaviruses were found to be increasing rapidly. They were found to occur in a number of animal species including mice, rats, cats, dogs, turkeys, chickens, pigs and rabbits. The animal studies were not limited to respiratory tract infections but also included encephalitis, hepatitis, and gastroenteritis [17]. Based on genetic and antigenic studies human and animal coronaviruses where categorised into three broad groups [18] (Table 1).

Table 1: Broad category of human and animal coronaviruses.

\begin{tabular}{|l|l|}
\hline \multicolumn{1}{|c|}{ Category } & \multicolumn{1}{|c|}{ Coronavirus } \\
\hline Group I $(\alpha-\mathrm{CoVs})$ & $\begin{array}{l}229 \mathrm{E} \text { and other similar } \\
\text { viruses }\end{array}$ \\
\hline Group II $(\beta-\mathrm{CoVs})$ & OC43 \\
\hline Group III $(\gamma-\mathrm{CoV})$ & $\begin{array}{l}\text { Avian infectious bronchitis } \\
\text { virus and other related avian } \\
\text { viruses }\end{array}$ \\
\hline
\end{tabular}

\section{Severe Acute Respiratory Syndrome (SARS) Coronavirus}

The SARS coronavirus and new form of the virus emerged from China in the late 2002 and early 2003 and spread throughout the world [19-21]. These viruses grew easily in tissue culture helping in studying the genomic structure of the virus which were found to be sufficiently different from human and animal coronavirus and thus formed a new group of virus similar to viruses cultured from Himalayan palm civets, from which they were presumed to be emerged [22]. During SARS outbreak 29 countries were affected with more than 8000 reported cases and around 770 mortalities [23]. It is still unclear how these viruses entered human population. One theory suggest that Himalayan palm civets acted as a reservoir for these viruses.

\section{Genomic structure of coronavirus}

Coronavirus belongs to the order Nidovirales, family Coronaviridae and subfamily Coronavirinae. This subfamily is further divided into alpha, beta, gamma and delta coronaviruses based on phylogenetic clustering. These viruses are made up of enveloped single-stranded RNA genome of size range 26-32 kilobases. The genome contains a $5^{\prime}$ cap structure along with a $3^{\prime}$ poly
(A) tail, helping it to act as mRNA for translation of the replicase polyproteins [24]. The $5^{\prime}$ end of the coronavirus genome contains untranslated region and a leader sequence that contains multiple loop structures which assists in RNA transcription and replication. Transcriptional regulatory sequences are also present at the beginning of each structural gene assisting in their expression. The 3'UTR part also contains RNA structures which assists in replication and synthesis of viral RNA. The accessory proteins present in corona virus are non-essential for replication in tissue culture; however, some have shown to play important roles in viral pathogenesis [25].

Virions of coronaviruses are spherical in shape and about $125 \mathrm{~nm}$ in diameter as confirmed by cryo-electron microscopic and tomographic technique [26,27]. They have club shape like projections from the surface. Inside the virion envelope there is nucleocapsid which are helically symmetrical common to negative sense RNA virus pathogenesis [24]. The virions four main structural proteins namely the spike, membrane, envelope and nucleocapsid encoded at the $3^{\prime}$ end of the viral genome. A fifth structural protein namely the hemagglutinin esterase is also present in the subset of $\beta$-coronaviruses which binds sialic acids on the surface glycoprotein and have acetyl-esterase activity [28]. These activities enhance the $S$ protein-mediated cell entry and virus spread through the mucosa [29].

\section{Life cycle of coronavirus}

The life cycle of a coronavirus is subdivided into four phases: (i) entry and attachment (ii) replicase protein expression (iii) replication and transcription (iv) assemble and release. Interaction between the $\mathrm{S}$ protein and its receptors marks initial attachment of the virion to the host cell. The interaction between the $\mathrm{S}$ protein and receptor is the primary determinant for a coronavirus to infect the host and it also governs the tissue tropism of the virus. Peptidase acts as the cellular receptor for most of the coronaviruses. After the receptor binding the virus gains access to the cytosol of the host cell [30,31]. This process is assisted by the acid dependent proteolytic cleavage of S protein called the cathepsin or another similar protease which is followed by the fusion of the cellular and viral membranes. Two cleavages are formed in the S2 portion of the protein, one is important for separating the receptor binding and fusion domain of $\mathrm{S}$ protein [32] and the other is important for exposing the fusion peptide. Most of the fusion occurs within the acidified endosomes however, some coronaviruses may fuse at the plasma membrane site. 
The entry and attachment of virion is followed by replicase protein expression in which the translation of the replicase gene occurs within the virion genomic RNA. Two large ORFS namely rep1a and rep1b is encoded by replicase gene which in turn expresses two co-terminal polyproteins namely ppla and pplab. To get both the polyproteins expressed, the virus utilizes a slippery sequence (5'-UUUAAAC-3') and an RNA pseudoknot which causes the ribosomal frameshifting from the rep1a reading frame into the rep1b ORF [33]. The polyproteins ppla and pplab contain the nsps 1-11 and 1-16, respectively. In pp1ab, nsp11 from pp1a becomes nsp12 following extension of pp1a into pp1b. The nsps gets assembled into the replicase-transcriptase complex (RTC) thus creating an ambient environment for RNA synthesis, and ultimately are responsible for RNA replication and transcription of the sub-genomic RNAs [24].

Assembly and translation occur after the viral RNA synthesis in which both the genomic and sub-genomic RNAs are produced. Sub-genomic RNAs serve as mRNAs for the accessory and structural genes which resides at the downstream of the replicase polyproteins. Both genomic and sub-genomic RNAs are produced through the negative strand intermediates. Finally, coronaviruses are also known for their unique ability to recombine using both homologous and nonhomologous recombination $[34,35]$.

$\mathrm{S}, \mathrm{E}$, and $\mathrm{M}$ viral structure proteins are translated and inserted into the endoplasmic reticulum (ER) following the replication and sub-genomic RNA synthesis. These proteins are capable of moving along the secretory pathway into the endoplasmic reticulum-Golgi intermediate compartment (ERGIC) [36,37]. There, viral genomes get encapsulated by $\mathrm{N}$ protein bud into membranes of the ERGIC which contains the viral structural proteins thus forming mature virions [38]. These virions get transported to the cell surface and gets released by the process of exocytosis.

\section{Human and animal coronavirus disease}

Coronaviruses were thought to cause only mild respiratory infection before the outbreak of SARS-CoV. Recent studies suggest that coronaviruses are the cause of $15-30 \%$ of the respiratory tract infections in human every year. Infants, elderly and people with underlying illness are more prone to these viruses. HCoV-NL63, a novel coronavirus has been associated with acute laryngotracheitis [39]. Transmission of SARS-CoV only occurred through direct contact with infected individuals after the onset of illness. Thus, the outbreak was largely confined to households and healthcare settings [40], except for few reported cases of superspreading events. SARS-CoV outbreak was controlled in June 2003. SARS-CoV has not returned since then, however in 2012 a novel human coronavirus emerged in the Middle East which was called the Middle East Respiratory Syndrome-CoV (MERS$\mathrm{CoV})$. It caused highly pathogenic respiratory tract infections in Saudi Arabia and other close countries in the Middle East region [41]. High mortality rate of about $50 \%$ were reported during the early stages of the outbreak. However, the outbreak got controlled in 2013, although sporadic cases continued to be reported throughout the rest of the year. In April 2014, there was a sudden rise in the reported cases and deaths prompting fears of mutation being occurred in the virus making them capable of human-to-human transmission. As per the reports of European Center for Disease Prevention and Control a total of 855 cases of MERS-CoV were reported with 333 fatalities by August 2014 [24].

Coronaviruses are capable of causing a variety of diseases in animals like pigs, chickens, cows, cats and dogs causing major loss of economy and livestock. Porcine Epidemic Diarrhea Virus (PEDV) and Transmissible Gastroenteritis Virus (TGEV) causes severe gastroenteritis in piglets, Feline enteric coronavirus (FCoV) causes a mild or asymptomatic infection in domestic cats, Bovine $\mathrm{CoV}$ causes respiratory tract infections in cattle, Rat $\mathrm{CoV}$ causes respiratory tract infections in rats and Infectious Bronchitis Virus (IBV) cause mild to severe respiratory tract infections in cattle. Murine hepatitis virus (MHV) causes a variety of outcomes in mice, including enteric, respiratory, hepatic and neurologic infections [24].

\section{Pandemic COVID-19 outbreak}

The coronavirus disease of 2019 (COVID-19) first appeared in the Wuhan city of Hubei province in China and was declared a global health emergency by World Health Organization on 30th January 2020 [42]. As of 29th March 2020, WHO database confirms 574444 cases of corona globally with 26654 reported deaths from 201 countries [43]. However, this number is subjected to change every second. The most affected countries are Italy with more than 86000 confirmed cases and 9000 deaths, United states with 85000 confirmed cases and 1243 deaths and china with 82000 confirmed cases and 3300 deaths [44,45] (Figure 1).

The number of confirmed cases is increasing every day with the availability of rapid testing kits. This pandemic is going to impact severely in the socioeconomic and psychological aspect. COVID-19 is being considered as devastating as World influenza epidemic of 1918. 
Elderly people and individuals with history of chronic illness are at higher risk of corona attack and mortality [46]. COVID-19 has a broad clinical spectrum with patients showing only mild and subclinical illness at the early phase of the disease [47,48]. Most of the patients of COVID-19 develops severe acute respiratory disease which requires intensive care and oxygen supplementation.

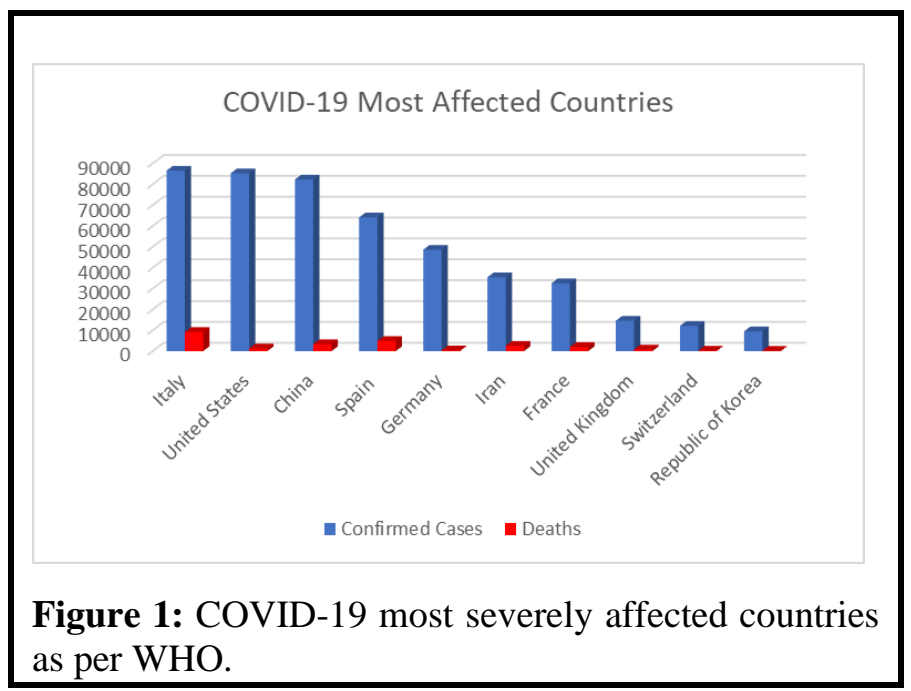

The exact transmission mode of this viral disease is not clearly understood however, chances of human to human transmission is suspected [49].

\section{Diagnosis}

The common symptoms which are present in a COVID19 patient includes fever, dry cough, fatigue and shortness of breath. However, some patients may even complain about sore throat, headache, diarrhoea, runny/stuffy nose and body ache. As per recommendations of World Health Organization (WHO) and Centers for Disease Control and Prevention (CDC) diagnostic testing for COVID-19 includes tracking the epidemiology and supressing the transmission of the virus. Initial diagnosis includes collecting the testing sample from the upper respiratory tract. Collection of the sample from nasopharyngeal region for swab-based SARS-COV-2 testing is highly recommended. However, alternatively oropharyngeal specimen, Nasal mid-turbinate swab, anterior nares specimen can also be exploited for the diagnosis purpose. CDC also recommends sampling from the lower respiratory tract for patients complaining of cough and sputum [50,51].

\section{Prevention}

WHO and CDC released a series of recommendations for the prevention and controlling the spreading of the disease [52,53]. Individuals were suggested:

i. To wash hands regularly with alcohol based handwash or sanitizer or daily using soaps.

ii. Avoid frequent touching of eyes, nose and mouth as they are the most exposed site for catching the infection.

iii. Maintaining social distance of about 1 metre between persons who are coughing or sneezing.

iv. Maintaining respiratory hygiene like covering mouth and nose while sneezing and coughing.

v. Wearing a face mask when in contact with another person

vi. Cleaning and sanitizing home and workplaces.

\section{Current medications and pipeline drugs}

Current these is no approved medication for the treatment of COVID-19. However, United States Food and Drug Administration (USFDA) has provided an Emergency Use Authorization (EUA) to hydroxychloroquine sulfate and chloroquine phosphate to be used for patients with COVID-19 [54]. These drugs where conventionally used as antimalarials. Strong clinical data is still required to support the longterm efficacy of both of these drugs in COVID-19. Favilavir, an antiviral drug has been approved by National Medical products Administration of China for the treatment of COVID-19. This drug has shown efficacy in treating the disease with minimal sideeffects. Remdesivir, another antiviral has gained attention of many researchers for treating the novel COVID-19 virus due to the similarity of COVID-19 to SARS and MERS viruses. Remdesivir, was previously successfully used in the SARS and MERS outbreak. It was also found effective against Ebola virus. However, more clinical data is needed to support its successful application. Some researchers also suggest supplementation by high doses of Vitamin-C may improve the condition of the patient. Vitamin-C boasts the immunity. But there is no scientific evidence in support of its activity in the treatment of COVID-19. A number of clinical trials are being conducted to develop novel diagnostic technique and medication for the effective treatment of the disease. This review summarizes the current clinical trials which are under way in the United States (Table 2) [55]. 
Citation: Jahangir MA, Muheem A, Rizvi MF, et al. Coronavirus (COVID-19): History, Current Knowledge and Pipeline Medications. Int J Pharm Pharmacol 2020; 4: 140. doi:10.31531/2581-3080.1000140

Table 2: List of clinical trials on coronavirus registered in the United States.

\begin{tabular}{|c|c|c|c|c|c|c|}
\hline $\begin{array}{c}\text { NCT } \\
\text { Number }\end{array}$ & Title & Conditions & Interventions & $\begin{array}{c}\text { Sponsors/ } \\
\text { Collaborators }\end{array}$ & Phases & $\begin{array}{l}\text { Study } \\
\text { Type }\end{array}$ \\
\hline $\begin{array}{l}\text { NCT043152 } \\
98\end{array}$ & $\begin{array}{l}\text { Evaluation of the } \\
\text { Efficacy and } \\
\text { Safety of } \\
\text { Sarilumab in } \\
\text { Hospitalized } \\
\text { Patients With } \\
\text { COVID-19 }\end{array}$ & COVID-19 & Sarilumab & $\begin{array}{l}\text { Regeneron } \\
\text { Pharmaceuticals/San } \\
\text { ofi }\end{array}$ & $\begin{array}{l}\text { Phase 2/ } \\
\text { Phase } 3\end{array}$ & $\begin{array}{l}\text { Interventio } \\
\text { nal }\end{array}$ \\
\hline $\begin{array}{l}\text { NCT043129 } \\
97\end{array}$ & $\begin{array}{l}\text { The Use of PUL- } \\
042 \text { Inhalation } \\
\text { Solution to } \\
\text { Reduce the } \\
\text { Severity of } \\
\text { COVID-19 in } \\
\text { Adults Positive } \\
\text { for SARS-CoV-2 } \\
\text { Infection }\end{array}$ & COVID-19 & $\begin{array}{l}\text { PUL-042 } \\
\text { Inhalation } \\
\text { Solution }\end{array}$ & Pulmotect, Inc. & Phase 2 & $\begin{array}{l}\text { Interventio } \\
\text { nal }\end{array}$ \\
\hline $\begin{array}{l}\text { NCT043170 } \\
40\end{array}$ & $\begin{array}{l}\text { CD24Fc as a } \\
\text { Non-antiviral } \\
\text { Immunomodulato } \\
\mathrm{r} \text { in COVID-19 } \\
\text { Treatment }\end{array}$ & $\begin{array}{l}\text { Severe } \\
\text { Coronaviru } \\
\text { s Disease } \\
\text { (COVID- } \\
19) \\
\end{array}$ & $\mathrm{CD} 24 \mathrm{~F}$ & OncoImmune, Inc. & Phase 3 & $\begin{array}{l}\text { Interventio } \\
\text { nal }\end{array}$ \\
\hline $\begin{array}{l}\text { NCT043184 } \\
44\end{array}$ & $\begin{array}{l}\text { Hydroxychloroqu } \\
\text { ine Post } \\
\text { Exposure } \\
\text { Prophylaxis for } \\
\text { Coronavirus } \\
\text { Disease } \\
\text { (COVID-19) }\end{array}$ & $\begin{array}{l}\text { COVID- } \\
19, \text { Corona } \\
\text { Virus } \\
\text { Infection }\end{array}$ & $\begin{array}{l}\text { Hydroxychloroqu } \\
\text { ine }\end{array}$ & Columbia University & $\begin{array}{l}\text { Phase } \\
2 / \text { Phase } \\
3\end{array}$ & $\begin{array}{l}\text { Interventio } \\
\text { nal }\end{array}$ \\
\hline $\begin{array}{l}\text { NCT043205 } \\
11\end{array}$ & $\begin{array}{l}\text { Beaumont } \\
\text { Quantitative } \\
\text { Lung Function } \\
\text { Imaging to } \\
\text { Characterize } \\
\text { Patients With } \\
\text { SARS-COV 2 }\end{array}$ & $\begin{array}{l}\text { SARS- } \\
\text { COV2, } \\
\text { Severe } \\
\text { Acute } \\
\text { Respiratory } \\
\text { Syndrome, } \\
\text { COVID-19 }\end{array}$ & CT-V & $\begin{array}{l}\text { William Beaumont } \\
\text { Hospitals }\end{array}$ & & $\begin{array}{l}\text { Observatio } \\
\text { nal }\end{array}$ \\
\hline $\begin{array}{l}\text { NCT043054 } \\
57\end{array}$ & $\begin{array}{l}\text { Nitric Oxide Gas } \\
\text { Inhalation } \\
\text { Therapy for } \\
\text { Mild/Moderate } \\
\text { COVID-19 }\end{array}$ & $\begin{array}{l}\text { Coronaviru } \\
\text { s } \\
\text { Infections, } \\
\text { Pneumonia } \\
\text {, Viral, } \\
\text { Acute } \\
\text { Respiratory } \\
\text { Distress } \\
\text { Syndrome } \\
\end{array}$ & Nitric Oxide & $\begin{array}{l}\text { Massachusetts } \\
\text { General } \\
\text { Hospital/Xijing } \\
\text { Hospital/Fondazione } \\
\text { IRCCS Ca' Granda, } \\
\text { Ospedale Maggiore } \\
\text { Policlinico }\end{array}$ & Phase 2 & $\begin{array}{l}\text { Interventio } \\
\text { nal }\end{array}$ \\
\hline $\begin{array}{l}\text { NCT043120 } \\
09\end{array}$ & $\begin{array}{l}\text { Losartan for } \\
\text { Patients With } \\
\text { COVID-19 } \\
\text { Requiring } \\
\text { Hospitalization }\end{array}$ & $\begin{array}{l}\text { Corona } \\
\text { Virus } \\
\text { Infection, } \\
\text { Acute } \\
\text { Respiratory } \\
\text { Distress }\end{array}$ & Losartan & $\begin{array}{l}\text { University of } \\
\text { Minnesota }\end{array}$ & Phase 2 & $\begin{array}{l}\text { Interventio } \\
\text { nal }\end{array}$ \\
\hline
\end{tabular}




\begin{tabular}{|c|c|c|c|c|c|c|}
\hline & & $\begin{array}{l}\text { Syndrome, } \\
\text { SARS- } \\
\text { CoV } \\
\text { Infection } \\
\end{array}$ & & & & \\
\hline $\begin{array}{l}\text { NCT043116 } \\
97\end{array}$ & $\begin{array}{l}\text { Intravenous } \\
\text { Aviptadil for } \\
\text { COVID-19 } \\
\text { Associated Acute } \\
\text { Respiratory } \\
\text { Distress }\end{array}$ & $\begin{array}{l}\text { Acute } \\
\text { Respiratory } \\
\text { Distress } \\
\text { Syndrome, } \\
\text { Corona } \\
\text { Virus } \\
\text { Infection } \\
\end{array}$ & Aviptadil i.v. & $\begin{array}{l}\text { NeuroRx, Inc./Relief } \\
\text { Therapeutics Holding } \\
\text { SA }\end{array}$ & Phase 2 & $\begin{array}{l}\text { Interventio } \\
\text { nal }\end{array}$ \\
\hline $\begin{array}{l}\text { NCT043063 } \\
93\end{array}$ & $\begin{array}{l}\text { Nitric Oxide Gas } \\
\text { Inhalation in } \\
\text { Severe Acute } \\
\text { Respiratory } \\
\text { Syndrome in } \\
\text { COVID-19 }\end{array}$ & $\begin{array}{l}\text { Severe } \\
\text { Acute } \\
\text { Respiratory } \\
\text { Syndrome }\end{array}$ & Nitric Oxide Gas & $\begin{array}{l}\text { Massachusetts } \\
\text { General } \\
\text { Hospital/Xijing } \\
\text { Hospital/Fondazione } \\
\text { IRCCS Ca' Granda, } \\
\text { Ospedale Maggiore } \\
\text { Policlinico/Niguarda } \\
\text { Hospital } \\
\end{array}$ & Phase 2 & $\begin{array}{l}\text { Interventio } \\
\text { nal }\end{array}$ \\
\hline $\begin{array}{l}\text { NCT043237 } \\
87\end{array}$ & $\begin{array}{l}\text { Viral Infection } \\
\text { and Respiratory } \\
\text { Illness Universal } \\
\text { Study [VIRUS]: } \\
\text { COVID19 } \\
\text { Registry }\end{array}$ & $\begin{array}{l}\text { Coronaviru } \\
\mathrm{s}\end{array}$ & observational & Mayo Clinic & & $\begin{array}{l}\text { Observatio } \\
\text { nal }\end{array}$ \\
\hline $\begin{array}{l}\text { NCT043256 } \\
72\end{array}$ & $\begin{array}{l}\text { Convalescent } \\
\text { Plasma to Limit } \\
\text { Coronavirus } \\
\text { Associated } \\
\text { Complications } \\
\end{array}$ & $\begin{array}{l}\text { Coronaviru } \\
\mathrm{s}\end{array}$ & $\begin{array}{l}\text { Convalescent } \\
\text { Plasma }\end{array}$ & Mayo Clinic & Phase 2 & $\begin{array}{l}\text { Interventio } \\
\text { nal }\end{array}$ \\
\hline $\begin{array}{l}\text { NCT043238 } \\
39\end{array}$ & $\begin{array}{l}\text { PRIORITY } \\
\text { (Pregnancy } \\
\text { CoRonavIrus } \\
\text { Outcomes } \\
\text { RegIsTrY) }\end{array}$ & $\begin{array}{l}\text { Pregnancy } \\
\text { in COVID- } \\
19\end{array}$ & $\begin{array}{l}\text { Pregnant women } \\
\text { under } \\
\text { investigation for } \\
\text { Coronavirus or } \\
\text { diagnosed with } \\
\text { COVID-19 } \\
\end{array}$ & $\begin{array}{l}\text { University of } \\
\text { California, San } \\
\text { Francisco/University } \\
\text { of California, Los } \\
\text { Angeles }\end{array}$ & & $\begin{array}{l}\text { Observatio } \\
\text { nal }\end{array}$ \\
\hline $\begin{array}{l}\text { NCT042834 } \\
61\end{array}$ & $\begin{array}{l}\text { Safety and } \\
\text { Immunogenicity } \\
\text { Study of 2019- } \\
\text { nCoV Vaccine } \\
\text { (mRNA-1273) to } \\
\text { Prevent SARS- } \\
\text { CoV-2 Infection }\end{array}$ & $\begin{array}{l}\text { Corona } \\
\text { Virus } \\
\text { Infection }\end{array}$ & mRNA-1273 & $\begin{array}{l}\text { National Institute of } \\
\text { Allergy and } \\
\text { Infectious Diseases } \\
\text { (NIAID) }\end{array}$ & Phase 1 & $\begin{array}{l}\text { Interventio } \\
\text { nal }\end{array}$ \\
\hline $\begin{array}{l}\text { NCT043213 } \\
69\end{array}$ & $\begin{array}{l}\text { Impact of Swab } \\
\text { Site and Sample } \\
\text { Collector on } \\
\text { Testing } \\
\text { Sensitivity for } \\
\text { SARS-CoV-2 } \\
\text { Virus in } \\
\text { Symptomatic } \\
\text { Individuals } \\
\end{array}$ & $\begin{array}{l}\text { Respiratory } \\
\text { infections }\end{array}$ & $\begin{array}{l}\text { Testing } \\
\text { Sensitivity for } \\
\text { SARS-CoV-2 } \\
\text { Virus in } \\
\text { Symptomatic } \\
\text { Individuals }\end{array}$ & $\begin{array}{l}\text { Dr. Deneen } \\
\text { Vojta/Quest } \\
\text { Diagnostics/Bill and } \\
\text { Melinda Gates } \\
\text { Foundation/UnitedHe } \\
\text { alth Group }\end{array}$ & & $\begin{array}{l}\text { Observatio } \\
\text { nal }\end{array}$ \\
\hline
\end{tabular}




\begin{tabular}{|c|c|c|c|c|c|c|}
\hline $\begin{array}{l}\text { NCT042928 } \\
99\end{array}$ & $\begin{array}{l}\text { Study to Evaluate } \\
\text { the Safety and } \\
\text { Antiviral Activity } \\
\text { of Remdesivir } \\
\text { (GS-5734â,,ф) in } \\
\text { Participants with } \\
\text { Severe } \\
\text { Coronavirus } \\
\text { Disease } \\
\text { (COVID-19) }\end{array}$ & COVID-19 & Remdesivir & Gilead Sciences & Phase 3 & $\begin{array}{l}\text { Interventio } \\
\text { nal }\end{array}$ \\
\hline $\begin{array}{l}\text { NCT042807 } \\
05\end{array}$ & $\begin{array}{l}\text { Adaptive } \\
\text { COVID-19 } \\
\text { Treatment Trial } \\
\text { (ACTT) } \\
\end{array}$ & $\begin{array}{l}\text { Corona } \\
\text { Virus } \\
\text { Infection }\end{array}$ & Remdesivir & $\begin{array}{l}\text { National Institute of } \\
\text { Allergy and } \\
\text { Infectious Diseases } \\
\text { (NIAID) }\end{array}$ & Phase 3 & $\begin{array}{l}\text { Interventio } \\
\text { nal }\end{array}$ \\
\hline $\begin{array}{l}\text { NCT043086 } \\
68\end{array}$ & $\begin{array}{l}\text { Post-exposure } \\
\text { Prophylaxis / } \\
\text { Preemptive } \\
\text { Therapy for } \\
\text { SARS- } \\
\text { Coronavirus-2 }\end{array}$ & $\begin{array}{l}\text { Corona } \\
\text { Virus } \\
\text { Infection, } \\
\text { SARS- } \\
\text { CoV } \\
\text { Infection } \\
\end{array}$ & $\begin{array}{l}\text { Hydroxychloroqu } \\
\text { ine }\end{array}$ & $\begin{array}{l}\text { University of } \\
\text { Minnesota }\end{array}$ & Phase 3 & $\begin{array}{l}\text { Interventio } \\
\text { nal }\end{array}$ \\
\hline
\end{tabular}

\section{Conclusion}

Advancements in coronavirology has taken a giant leap in the recent years. The SARS and MERS epidemic where the reminders about the emergence of novel coronavirus and its potential threat to the human population. The novel coronavirus is significantly similar to the SARS and MERS viruses. But still we do not know much about the possible treatment strategy for this novel virus. They are causing a variety of human and animal veterinary diseases. Future researches are necessary to investigate replication and pathogenesis. COVID-19 outbreak is a setback to our preparation for tackling such pandemic situation. About 30000 people have died of the disease. There is no approved medication for the disease. However, USFDA has provided an Emergency Use Authorization (EUA) to hydroxychloroquine sulfate and chloroquine phosphate to be used for patients with COVID-19. More data are required to support its success in the treatment. A number of researches and clinical trials are being conducted to bring out a possible treatment for the disease. But till date prevention is the best way to tackle this pandemic situation.

\section{References}

1. Tyrrell DA, Bynoe ML. Cultivation of viruses from a high proportion of patients with colds. Lancet 1966; 1: 76-77.

2. Hamre D, Procknow JJ. A new virus isolated from the human respiratory tract. Proc Soc Exp Biol Med 1966; 121: 190-193.
3. McIntosh K, Dees JH, Becker WB, et al. Recovery in tracheal organ cultures of novel viruses from patients with respiratory disease. Proc Natl Acad Sci USA 1967; 57: 933-940.

4. Almeida JD, Tyrrell DA. The morphology of three previously uncharacterized human respiratory viruses that grow in organ culture. J Gen Virol 1967; 1: 175-178.

5. McIntosh K, Becker WB, Chanock RM. Growth in suckling-mouse brain of "IBV-like" viruses from patients with upper respiratory tract disease. Proc Natl Acad Sci USA 1967; 58: 2268-2273.

6. Witte KH, Tajima M, Easterday BC. Morphologic characteristics and nucleic acid type of transmissible gastroenteritis virus of pigs. Arch Gesamte Virusforsch 1968; 23: 53-70.

7. Tyrrell DA, Almeida JD, Cunningham $\mathrm{CH}$, et al. Coronaviridae. Intervirology 1975; 5: 76-82.

8. McIntosh K, Kapikian AZ, Turner HC, et al. Seroepidemiologic studies of coronavirus infection in adults and children. Am J Epidemiol 1970; 91: 585-592.

9. Bradburne AF. Antigenic relationships amongst coronaviruses. Archiv Gesamte Virusforsch 1970; 31: 352-364.

10. McIntosh K, Kapikian AZ, Hardison KA, et al. Antigenic relationships among the coronaviruses of man and between human and animal coronaviruses. J Immunol 1969; 102: 1109-1118.

11. Bradburne AF, Bynoe ML, Tyrrell DA. Effects of a "new" human respiratory virus in volunteers. $\mathrm{Br}$ Med J 1967; 3: 767-769. 
12. Bradburne AF, Somerset BA. Coronative antibody tires in sera of healthy adults and experimentally infected volunteers. J Hyg (Lond) 1972; 70: 235244.

13. McIntosh K, Chao RK, Krause HE, Wasil R, Mocega HE. Coronavirus infection in acute lower respiratory tract disease of infants. J Infect Dis 1974; 130: 502-507.

14. Wenzel RP, Hendley JO, Davies JA, et al. Coronavirus infections in military recruits. Threeyear study with coronavirus strains OC43 and 229E. Am Rev Respir Dis 1974; 109: 621-624.

15. McIntosh K, Ellis EF, Hoffman LS, et al. Association of viral and bacterial respiratory infection with exacerbations of wheezing in young asthmatic children. Chest 1973; 63(suppl): 43S.

16. Falsey AR, Walsh EE, Hayden FG, et al. Rhinovirus and coronavirus infection-associated hospitalizations among older adults. J Infect Dis 2002; 185: 1338-1341.

17. Haring J, Pearlman S. Mouse hepatitis virus. Curr Opin Microbiol 2001; 4: 462-466.

18. Lai MM, Holmes KV. Coronaviridae: the viruses and their replication. In: Knipe DM, Howley PM, eds. Fields Virology. Philadelphia, PA: LippincottRaven 2001.

19. Drosten C, Gunther S, Preiser W, et al. Identification of a novel coronavirus in patients with severe acute respiratory syndrome. N Engl J Med 2003; 348: 1967-1976.

20. Ksiazek TG, Erdman D, Goldsmith CS, et al. A novel coronavirus associated with severe acute respiratory syndrome. N Engl J Med 2003; 348: 1953-1966.

21. Peiris JS, Lai St, Poon LL, et al. Coronavirus as a possible cause of severe acute respiratory syndrome. Lancet 2003; 361: 1319-1325.

22. Guan Y, Zheng BJ, He YQ, et al. Isolation and characterization of viruses related to the SARS coronavirus from animals in southern China. Science 2003; 302: 276-278.

23. Centers for Disease Control and Prevention. http://www.cdc.gov/ncidod/sars/index.html

24. Fehr AR, Perlman S. Coronaviruses: an overview of their replication and pathogenesis. Methods Mol Biol 2015; 1282: 1-23.

25. Zhao L, Jha BK, Wu A, et al. Antagonism of the interferon-induced OAS-RNase $\mathrm{L}$ pathway by murine coronavirus ns 2 protein is required for virus replication and liver pathology. Cell host microbe 2012; 11: 607-616.

26. Barcena M, Oostergetel GT, Bartelink W, et al. Cryo-electron tomography of mouse hepatitis virus: Insights into the structure of the coronavirion.
Proceedings of the National Academy of Sciences of the United States of America 2009; 106: 582587.

27. Neuman BW, Adair BD, Yoshioka C, et al. Supramolecular architecture of severe acute respiratory syndrome coronavirus revealed by electron cryomicroscopy. J Virology 2006; 80: 7918-7928.

28. Klausegger A, Strobl B, Regl G, et al. Identification of a coronavirus hemagglutinin-esterase with a substrate specificity different from those of influenza $\mathrm{C}$ virus and bovine coronavirus. J Virology 1999; 73: 3737-3743.

29. Cornelissen LA, Wierda CM, van der Meer FJ, et al. Hemagglutinin-esterase, a novel structural protein of torovirus. J Virology 1997; 71: 52775286.

30. Kubo H, Yamada YK, Taguchi F. Localization of neutralizing epitopes and the receptor-binding site within the amino-terminal 330 amino acids of the murine coronavirus spike protein. J Virol 1994; 68: 5403-5410.

31. Cheng PK, Wong DA, Tong LK, et al. Viral shedding patterns of coronavirus in patients with probable severe acute respiratory syndrome. Lancet 2004; 363: 1699-1700.

32. Elouzard S, Chu VC, Whittaker GR. Activation of the SARS coronavirus spike protein via sequential proteolytic cleavage at two distinct sites. Proceedings of the National Academy of Sciences of the United States of America 2009; 106: 58715876.

33. Araki K, Gangappa S, Dillehay DL, Rouse BT, et al. Pathogenic virus-specific $\mathrm{T}$ cells cause disease during treatment with the calcineurin inhibitor FK506: implications for transplantation. J Exp Med 2010; 207: 2355-2367.

34. Keck JG, Makino S, Soe LH, et al. RNA recombination of coronavirus. Adv Exp Med Bio 1987; 218: 99-107.

35. Lai MM, Baric RS, Makino S, et al. Recombination between nonsegmented RNA genomes of murine coronaviruses. J Virology 1985; 56: 449-456.

36. Krijnse-Locker J, Ericsson M, Rottier PJM, et al. Characterization of the budding compartment of mouse hepatitis virus: Evidence that transport from the RER to the golgi complex requires only one vesicular transport step. J Cell Biol 1994; 124: 5570.

37. Tooze J, Tooze S, Warren G. Replication of coronavirus MHV-A59 in sac- cells: determination of the first site of budding of progeny virions. European J Cell Bio 1984; 33: 281-293. 
38. de Haan CA, Rottier PJ. Molecular interactions in the assembly of coronaviruses. Adv Virus Res 2005; 64: 165-230.

39. van der Hoek L, Sure K, Ihorst G, et al. Croup is associated with the novel coronavirus NL63. PLoS Med 2005; 2: e240.

40. Peiris JS, Yuen KY, Osterhaus AD, et al. The severe acute respiratory syndrome. N Engl J Med 2003; 349: 2431-2441.

41. Zaki AM, van Boheemen S, Bestebroer TM, et al. Isolation of a novel coronavirus from a man with pneumonia in Saudi Arabia. N Engl J Med 2012; 367: 1814-1820.

42. https://www.who.int/news-room/detail/30-012020-statement-on-the-second-meeting-of-theinternational-health-regulations-(2005)emergency-committee-regarding-the-outbreak-ofnovel-coronavirus-(2019-ncov)

43. https://www.who.int/

44. https://www.who.int/emergencies/diseases/novelcoronavirus-2019

45. https://experience.arcgis.com/experience/685d0ace 521648f8a5beeeee1b9125cd

46. Belluz J. China's cases of Covid-19 are finally declining. A WHO expert explains why. https://www.vox.com/2020/3/2/21161067/coronav irus-covid19-china

47. Guan W, Ni Z, Hu Y, et al. Clinical Characteristics of Coronavirus Disease 2019 in China. N Engl J Med 2020; NEJMoa2002032.

48. Wang D, Hu B, Hu C, et al. Clinical Characteristics of 138 Hospitalized Patients With 2019 Novel Coronavirus-Infected Pneumonia in Wuhan, China. JAMA 2020.

49. Phan LT, Nguyen TV, Luong QC, et al. Importation and human-to-human transmission of a novel coronavirus in Vietnam. N Engl J Med 2020; 382: 872-874.

50. https://www.who.int/emergencies/diseases/novelcoronavirus-2019/technical-guidance/laboratoryguidance

51. https://www.cdc.gov/coronavirus/2019ncov/lab/guidelines-clinical-specimens.html

52. https://www.cdc.gov/coronavirus/2019ncov/prevent-getting-sick/prevention.html

53. https://www.who.int/emergencies/diseases/novelcoronavirus-2019/advice-for-public

54. https://www.fda.gov/news-events/pressannouncements/coronavirus-covid-19-updatedaily-roundup-march-30-2020

55. www.clinicaltrails.gov

This manuscript was peer-reviewed

Mode of Review: Single-blinded

Academic Editor: Dr. Syed Sarim Imam

Copyright: (2020 Jahangir MA, et al. This article is distributed under the terms of the Creative Commons Attribution 4.0 International License (http://creativecommons.org/licenses/by/4.0/), which permits unrestricted use, distribution, and reproduction in any medium, provided you give appropriate credit to the original author(s) and the source, provide a link to the Creative Commons license, and indicate if changes were made. 